\title{
Morbidity and Discomfort of Ten-Core Biopsy of the Prostate Evaluated by Questionnaire
}

\author{
A. Manseck K. Guhr M. Froehner O.W. Hakenberg M.P. Wirth \\ Department of Urology, Technical University of Dresden, Germany
}

\section{Key Words}

Prostate cancer · Transition zone biopsy - Transrectal ultrasound $\cdot$ Morbidity Prophylactic antibiotic treatment $\cdot$ Questionnaire

\begin{abstract}
Transition zone biopsies have been found to increase the detection rates of cancer of the prostate in patients with negative digital rectal examination. There are however no data available whether the higher biopsy rate is associated with greater morbidity. The present study was therefore designed to evaluate the complication rate of extended sextant biopsy. In this prospective study, 162 consecutive patients who presented for prostatic evaluation were included. After starting prophylactic antibiotic treatment $48 \mathrm{~h}$ prior to the procedure, transrectal ultrasound-guided core biopsies were obtained from each lobe: three each from the peripheral zone (apex, midzone and base) and two from the transition zone of each prostatic lobe. In all patients a questionnaire was obtained 10-12 days after the procedure. Major complications occurred in 3 patients. In 2 of the 3 cases major macroscopic hematuria was treated by an indwelling catheter for 1 or 2 days and 1 patient developed fever $>38.5^{\circ} \mathrm{C}$ for 1 day. Minor macroscopic hematuria was
\end{abstract}

\section{KARGER}

Fax +41613061234

E-Mail karger@karger.ch

www.karger.com
(C) 2001 S. Karger AG, Basel

0042-1138/01/0664-0197\$17.50/0

Accessible online at:

www. karger.com/journals/uin present in $68.5 \%$ of the patients. In $17.9 \%$ of these cases, the hematuria lasted for more than 3 days. Hematospermia was observed in $19.8 \%$ and minor rectal bleeding occurred in $4.9 \%$. Ten-core biopsies did not lead to an increase in adverse effects or complications when compared to the results of sextant biopsies reported in the literature.

Copyright (C) 2001 S. Karger AG, Basel

\section{Introduction}

The diagnosis and treatment of prostate cancer $(\mathrm{CaP})$ requires histological proof. Ultrasound-guided systematic sextant biopsy of the prostate became the standard procedure for the histological confirmation of $\mathrm{CaP}$. However, in PSA screening studies there is a high rate of patients without the confirmation of a $\mathrm{CaP}(65.6-82.1 \%[1,2])$. In these patients a second set of sextant biopsies may be performed to rule out $\mathrm{CaP}$. Keetch et al. [3] could show that in serial prostatic biopsies, $79 \%$ of $\mathrm{CaP}$ are detected with the first set of biopsies, another $16.6 \%$ with the second and only $4.4 \%$ with further prostatic biopsies. According to Keetch et al. [3], a total of $95.6 \%$ of $\mathrm{CaP}$ can be detected with two sets of prostatic biopsies. For these reasons, some authors $[4,5]$ advocate a higher number of
Dr. med. Andreas Manseck

Department of Urology, University Hospital ‘Carl Gustav Carus'

Technical University of Dresden

Fetscherstrasse 74, D-01307 Dresden (Germany)

Tel. +49 3514582162 , Fax +493514584333 
biopsy cores expecting an improvement in the detection rate especially in large prostate glands. Different propositions have been made such as a five-region biopsy, taking far lateral biopsies or taking an individualized number of biopsy cores depending on the patient's age and the size of his prostate. Also, the concept of taking additional transition zone biopsies has been discussed, as McNeal et al. [6] could show that more than $20 \%$ of $\mathrm{CaP}$ originate in the transition zone only. Reissigl et al. [7] recently confirmed the data of McNeal et al. [6] (28\% tumors originated in the transition zone only and would not have been detected by standard sextant biopsy). However, the rate of complications by performing additional biopsies has to be taken into consideration, as the biopsy procedure is performed in $65.6-82.1 \%$ on healthy men. In the following study, a ten-core biopsy protocol, including four biopsies from the transition zone - taken as a model for an extended biopsy protocol - was therefore evaluated regarding the complication rate. In all patients, a questionnaire was obtained relating to complications and personal discomfort.

\section{Materials and Methods}

Between September 1997 and June 1998, men who were referred for prostate biopsy were admitted to this prospective study after informed consent. Indications for prostate biopsy were an elevation in the serum PSA and/or a digital rectal examination (DRE) suspicious for CaP. A total of 162 consecutive men was evaluated. None of the patients had a history of open or transurethral prostate surgery or prior radiation therapy. In all cases, DRE was performed and classified as benign, benign enlargement or suspicious. For prophylactic antibiotic treatment, ciprofloxacin $(2 \times 250 \mathrm{mg}$ b.d. $)$ was administered for 5 days, beginning 2 days before the procedure. Men with a known bleeding tendency were prepared according to the underlying disorder. Patients with urinary tract infections had their procedure postponed and received antibiotics corresponding to urinary culture and sensitivity testing. Careful counseling relative to the possible complications was carried out with special emphasis on the clinical importance of infectious side effects and the need for immediate treatment. Both oral and written consent was obtained. All men underwent real time transrectal ultrasound using a 7.5-MHz biplanar ultrasound probe (Siemens Versa ${ }^{\circledR}$ ). Core biopsies were obtained by an automatic biopsy device (BioptyGun ${ }^{\circledR}$ ). From each lobe, five cores were taken: three ultrasound-guided cores from the peripheral zone (apex, mid-zone and base) and two from the transition zone. All tumors were classified according to the TNM classification of 1997 [8].

The clinical intra- and perioperative complications were documented. All patients were followed until complications disappeared. Ten to 12 days after the procedure a urinalysis was done. At the same time, a questionnaire was given to all the patients. The questionnaire related to clinical hematuria, hematospermia, rectal bleeding, fever, pain during the procedure and later discomfort. One of the objectives of the questionnaire was to determine the length of post-procedural discomfort following transrectal biopsy. The distribution of parameters was assessed using the Mann-Whitney test.

\section{Results}

Patient age ranged from 37 to 79 years (mean 63.4). Serum PSA levels were elevated in 141 patients (PSA $\geq 4 \mathrm{ng} / \mathrm{ml}$; Abbott AxSym enzyme immunoassay). The mean PSA level was $13.5 \mathrm{ng} / \mathrm{ml}$ with a range from 0.4 to $210.0 \mathrm{ng} / \mathrm{ml}$. DRE was suspicious for $\mathrm{CaP}$ in 66 patients.

Table 1. Influence of the number of biopsies in bleeding complications after transrectal biopsy of the prostate

\begin{tabular}{lcclcc}
\hline Author, year & Patients & Cores & $\begin{array}{l}\text { Hematuria } \\
\%\end{array}$ & $\begin{array}{l}\text { Rectal } \\
\text { bleeding, \% }\end{array}$ & $\begin{array}{l}\text { Hemato- } \\
\text { spermia, \% }\end{array}$ \\
\hline Hodge et al. [15], 1989 & 251 & mean 6.2 & NR & 1.2 & NR \\
Vallencien et al. [16], 1989 & 167 & $1-2$ & 25 & 12 & 3 \\
Torp-Pedersen et al. [17], 1989 & 138 & $2-3$ & 37 & 9.4 & 5 \\
Gustafsson et al. [18], 1990 & 145 & $2-4$ & 39.3 & $\mathrm{NR}$ & 46 \\
Collins et al. [11], 1993 & 89 & $\geq 6$ & 58 & 37.1 & 28.1 \\
Aus et al. [13], 1993 & 391 & $1-5$ & 13 & 2.8 & 9 \\
Clements et al. [19], 1993 & 80 & $\leq 5$ & 20 & 7.5 & 11.3 \\
Hammerer and Huland [20], 1994 & 651 & 6 & 14 & 2 & 6 \\
Niesel et al. [10], 1995 & 76 & 6 & 48 & 4 & 28 \\
Enlund and Varenhorst [12], 1997 & 415 & $1-8$ (mean 4) & 49.6 & 21.7 & NR \\
Rietbergen et al. [2], 1997 & 1,687 & $6-7$ & $23.6^{\mathrm{a}}$ & 1.7 & 45.3 \\
Present series, 2000 & 162 & 10 & 17.9 a & 4.9 & 19.8 \\
\hline
\end{tabular}

$\mathrm{NR}=$ Not reported.

${ }^{\text {a }}$ Hematuria for more than 3 days. 
From each of the 162 patients, ten-core biopsies were obtained. In all but 1 patient, the biopsies were performed without general anesthesia on an outpatient procedure. The patients reported no or only minimal discomfort during the procedure. Histological examination revealed the diagnosis of $\mathrm{CaP}$ in 52 of the 162 patients (32.1\%). Tumor stages were classified as T1c $(n=10), T 2(n=24), T 3(n=$ $15)$, and T4 $(\mathrm{n}=3)$ according to the 1997 TNM classification [8]. Of the T2 cancers (according to the TNM classification) 15 had a positive DRE while 9 had a normal DRE but a suspicious lesion in TRUS.

The complications of the procedure are specified in tables 1-3. In 2 cases, severe macroscopic hematuria had to be treated by an indwelling catheter for 1 or 2 days. No bleeding necessitating blood transfusion occurred. Minor (macroscopic) hematuria was present in $68.5 \%$ of the patients; in $17.9 \%$ of these cases hematuria persisted for more than 3 days (table 2) and $4.9 \%$ of the patients had hematuria for more than 7 days. Thirty-two patients developed hematospermia (19.8\%). Minimal rectal bleeding was noted in $4.9 \%$. Surgical intervention was not required in any case. Urinary retention did not occur,

Table 2. Duration of hematuria after transrectal biopsy of the prostate

\begin{tabular}{lrr}
\hline Duration of hematuria & $\mathrm{n}$ & \multicolumn{1}{c}{$\%$} \\
\hline 0 & 51 & 31.5 \\
1 day & 37 & 22.8 \\
2-3 days & 45 & 27.8 \\
4-7 days & 21 & 13.0 \\
$\geqq 8$ days & 8 & 4.9 \\
\hline
\end{tabular}

while 24 patients $(14.8 \%)$ reported a temporarily obstructed micturition. Infectious complications such as septicemia $(n=0)$ or fever $\left(>38.5^{\circ} \mathrm{C} ; \mathrm{n}=1\right)$ were rare.

Ten to 12 days after this procedure, no patient had urinary tract infection (positive urine culture). The analysis of complications did not reveal significantly more complications in the group of patients with $\mathrm{CaP}$ than in men with a benign histology.

\section{Discussion}

PSA screening for prostate cancer led to a rapid increase in the numbers of prostate biopsies performed in the last years. For 1998, Landis et al. [9] estimated 184,500 new cases of CaP in the United States based on the Surveillance, Epidemiology and End Results data of the National Cancer Institute. Regarding the detection rate of the screening studies already mentioned above, in the United States the number of prostate biopsies performed can be estimated to be two- to threefold higher. This fact leads to the question of the morbidity of this diagnostic procedure, especially if the number of cores taken is increased. Although important improvements were made in the biopsy technique, e.g. the use of Tru-Cut needles instead of Silverman needles, spring-loaded biopsy guns instead of hand proceeded needles and ultrasound instead of digitally guided biopsies, severe complications of prostatic biopsy do occur.

In the present series, severe bleeding was found in 2 of 162 patients $(1.2 \%)$ which could be resolved by a shortterm indwelling catheter. Similar results were reported by Niesel et al. [10], who performed sextant biopsy and had to insert indwelling catheters in $2.6 \%$ of their patients.
Table 3. Influence of prophylactic antibiotic treatment and time of first application on the rate of clinical infection in patients with six or more biopsy cores
Morbidity and Discomfort of Ten-Core Biopsy

\begin{tabular}{lrllll}
\hline Author, year & Patients & $\begin{array}{l}\text { Prophylactic } \\
\text { antibiotic } \\
\text { treatment }\end{array}$ & $\begin{array}{l}\text { Time of first } \\
\text { application } \\
\text { hours before } \\
\text { biopsy }\end{array}$ & $\begin{array}{l}\text { Fever } \\
\%\end{array}$ & $\begin{array}{l}\text { Septi- } \\
\text { cemia } \\
\%\end{array}$ \\
\hline Kilner et al. [21], 1995 & 98 & N & - & 9 & NR \\
Hodge et al. [15], 1989 & 251 & Y & 1 & 0.8 & NR \\
Collins et al. [11], 1993 & 89 & Y & 1 & 4.5 & 0 \\
Hammerer and Huland [20], 1994 & 372 & Y & 1 & 0.5 & NR \\
Rietbergen et al. [2], 1997 & 1,687 & Y & 2 & 4.2 & 0.2 \\
Niesel et al. [10], 1995 & 76 & Y & 24 & 9.0 & 0 \\
Sieber et al. [14], 1997 & 4,439 & Y & 24 & 0.07 & 0 \\
Present series, 2000 & 162 & Y & 48 & 0.6 & 0 \\
\hline
\end{tabular}

$\mathrm{Y}=$ Yes; $\mathrm{N}=$ no; $\mathrm{NR}=$ not reported. 
Transfusion as a result of a major bleeding complication was never necessary after ten-core biopsies were taken. However, $17.9 \%$ of the patients reported minor bleeding such as hematuria for more than 3 days. This is in accordance with other studies on sextant biopsies, where hematuria was present in $14-58 \%$ of patients biopsied (table 1).

Theoretically, the number of cores taken should influence the rate of complications, as the risk for bleeding or infection should be the same for every single core. So the complication rate should increase with each additional core taken. Table 1 shows the results of studies with different numbers of cores taken and the reported bleeding complications. In contrast to the theoretical assumption, there is no obvious recognizable trend for more complications with increasing numbers of core biopsies (table 1). Hematuria ranges from 13 to $58 \%$, the same wide range exists for rectal bleeding (1.2-37.1\%) and hematospermia (3-46\%). Besides other reasons, this may be due to different study designs and ultrasound probes used. Manufacturers provide ultrasound probes of various sizes, biopsy angles and needle sleeves. The angle for the biopsy may in so far represent a potential risk factor, as narrow angles may result in a higher rate of bladder perforations in biopsies taken near the bladder neck. Furthermore, the needle sleeves may hold a possible risk for mucosal injury of the rectum.

Other important points are the infectious complications of transrectal prostatic biopsy. In this series, clinical infections were rarely seen, which is probably due to the antibiotic regimen of 5 days beginning 2 days prior to the procedure. So the rate of patients with fever $(0.6 \%)$ was rather low, and no additional risk by the extended biopsy could be found in comparison to the literature.

The questionnaire filled out by all patients showed that discomfort as well as hematuria and hematospermia may last longer than 8 days in a considerable number of patients. It is therefore important to inform the patients prior to the treatment.

In conclusion, the extension of six- to ten-core biopsies did not lead to a recognizable increase in adverse effects or complications when compared with the data of sextant biopsy reported in the literature.

\section{References}

1 Catalona WJ, Smith DS, Ratliff TL, Basler JW: Detection of organ-confined prostate cancer is increased through prostate-specific antigenbased screening. JAMA 1993;270:948-954

2 Rietbergen JBW, Boeken Kruger AE, Kranse $\mathrm{R}$, Schröder FH: Complications of transrectal ultrasound-guided systematic sextant biopsies of the prostate: Evaluation of complication rates and risk factors within a population-based screening program. Urology 1997;49:875-880.

3 Keetch DW, Catalona WJ, Smith DS: Serial prostatic biopsies in men with persistently elevated serum prostate specific antigen values. $\mathrm{J}$ Urol 1994;151:1571-1574.

4 Belville WD: Are T1c tumors different from incidental tumors found at autopsy? The risk and reality of overdetection. Semin Urol Oncol 1995; 13:181-186.

5 Vashi AR, Wojno KJ, Gillespie B, Oesterling JE: A model for the number of cores per prostate biopsy based on patient age and prostate gland volume. J Urol 1998;159:920-924.

6 McNeal JE, Redwine EA, Freiha FS, Stamey TA: Zonal distribution of prostatic adenocarcinoma. Am J Surg Pathol 1988;12:897-906.

7 Reissigl A, Pointner J, Strasser H, Ennemoser O, Klocker H, Bartsch G: Frequency and clinical significance of transition zone cancer in prostate cancer screening. Prostate 1997;30: $130-135$.
8 Wittekind C, Wagner G: TNM-Klassifikation maligner Tumoren, ed 5. Berlin, Springer, 1997.

9 Landis SH, Murray T, Bolden S, Wingo PA: Cancer statistics, 1998. Ca Cancer J Clin 1998; 48:6-29.

10 Niesel T, Breul J, Löffler E, Leyh H, Hartung $\mathrm{R}$ : Die ultraschallgesteuerte transrektale 'mapping'-Biopsie der Prostata - Korrelation zum Operationspräparat und Verträglichkeit beim Patienten. Akt Urol 1995;26:244-248.

11 Collins GN, Lloyd SN, Hehir M, McKelvie GB: Multiple transrectal ultrasound-guided prostatic biopsies - True morbidity and patient acceptance. Br J Urol 1993;71:460-463.

12 Enlund AL, Varenhorst E: Morbidity of ultrasound-guided transrectal core biopsy of the prostate without prophylactic antibiotic therapy. A prospective study in 415 cases. Br J Urol 1997;79:777-780.

13 Aus G, Hermansson CG, Hugosson J, Pedersen $\mathrm{KV}$ : Transrectal ultrasound examination of the prostate: Complications and acceptance by patients. Br J Urol 1993;71:457-459.

14 Sieber PR, Rommel FM, Agusta VE, Breslin JA, Huffnagle HW, Harpster LE: Antibiotic prophylaxis in ultrasound guided transrectal prostate biopsy. J Urol 1997;157:2199-2200.
15 Hodge KK, McNeal JE, Stamey TA: Ultrasound guided transrectal core biopsies of the palpably abnormal prostate. J Urol 1989;142: 66-70.

16 Vallencien G, Prapotnich D, Sibert L, Lugagne PM, Veillon B, Brisset JM, Andre-Bougaran J: Comparison of the efficacy of digital rectal examination and transrectal ultrasonography in the diagnosis of prostatic cancer. Eur Urol 1989;16:321-324.

17 Torp-Pedersen S, Lee F, Littrup PJ, Sider DB, Kumasaka GH, Solomon MH, Mc Leary RD: Transrectal biopsy of the prostate guided with transrectal US: Longitudinal and multiplanar scanning. Radiology 1989;170:23-27.

18 Gustafsson O, Norming U, Nyman CR, Öhström M: Complications following combined transrectal aspiration and core biopsy of the prostate. Scand J Urol Nephrol 1990;24:249_ 251.

19 Clements R, Aideyan OU, Griffiths GJ, Peeling WB: Side effects and patients' acceptability of transrectal biopsy of the prostate. Clin Radiol 1993;47:125-126.

20 Hammerer P, Huland H: Systematic sextant biopsies in 651 patients referred for prostate evaluation. J Urol 1994;151:99-102.

21 Kilner SV, Woo HH, Rosario DJ, Chapple CR, Anderson JB: Morbidity of transrectal ultrasound and systematic sextant biopsies. J Urol 1995;153(suppl):986. 